\title{
Rekonstuksi Metode Belajar Kontektualis Santri Pondok Pesantren Salaf Dan Khalaf Di Madura
}

\author{
Zaitur Rahem \\ Institut Ilmu Keislaman Annuqayah Guluk-Guluk Sumenep Madura \\ Emai: zaitur_rahem@yahoo.co.id
}

\begin{abstract}
Abstrak:
Dunia pendidikan di Indonesia sering dibingungkan dengan persoalan pencarian metode belajar alternatif. Kebimbangan ini terjadi karena elemen pemerintah melihat, hasil dari proses yang dilakukan sejumlah lembaga pendidikan dinilai kurang maksimal. Beberapa perubahanan metode belajar telah dilakukan untuk mendapatkan hasil maksimal. Sehingga mengemuka pertanyaan, kegagalan pendidikan disebabkan oleh metode atau lebih karena factor sumber daya manusianya? Dalam perkembangannya, pondok pesantren dibagai menjadi salafiyah dan khalafiyah. Pondok pesantren dianggap sejumlah pihak sebagai kawah penuh inspirasi dan motivasi. Santri bisa belajar dengan dinamis. Meski dalam kampium keterbatasan. Proses di pondok pesantren selamana ini dipandang mampu menghasilkan produk berkarakter. Seperti apa realitas pondok pesantren salaf dengan khalaf.
\end{abstract}

Kata Kunci: Metode Belajar, Pesantren.

\begin{abstract}
:
The world of education in Indonesia is often confused with the question of finding alternative learning methods. This balance occurs because the elements of the government saw, the results of the process undertaken by some educational institutions considered less than the maximum. Several changes of learning method have been done to get maximum result. So that raises the question, the failure of education caused by the method or more because of the human resources factor? The reality of early education, represented by traditional educational institutions archipelago, boarding school. In its development, Boarding School is divided into salafiyah and khalafiyah. Boarding School is considered a number of parties as a crater full of inspiration and motivation. Students can learn dynamically. Although in the campium limitations. The process at this Boarding School boarding house is considered capable of producing character products. What is the reality of Boarding School salaf cottage with khalaf.
\end{abstract}

Keyword : Alternatif, salaf, khalaf 


\section{Pedahuluan}

Seiring perubahan zaman, peradaban manusia semakin maju. Gerak progresif peradaban ini, dapat dirasakan pada semua sector dan terjadi di semua pelosok dunia. Peradaban yang salah satu manfaatnya membawa nafas penyempurnaan status manusia di bumi. Tentu, irama peradaban manusia di bumi muncul bersamaan dengan kelindan waktu dan peralihan generasi. Manusia yang satu dengan yang lain, dari setiap generasi ke generasi berikutnya saling menyatu, menyempurnakan peradaban yang ada. Generasi hari ini menyempurnakan peradaban generasi sebelumnya. Generasi sebelumnya menyempurnakan perdaban sebelumnya juga. Satu generasi dengan generasi lainnya memiliki sisi prestasi, potensi, dan mimpi yang berbeda. Tergantung momentum dari generasi tersebut ada, beraktualiasi, dan berdomisili.

Peradaban memiliki makna hasil ${ }^{1}$. Hasil tesebut berupa karya, pemikiran, seni, budaya, ilmu pengetahuan, dan tekhnologi (teori ekanis). Hasil yang dimaksudkan dalam batasan ini adalah wujud nyata (bentuk kongkrit) dari sebuah proses yang dilakukan manusia. Manusia berproses dalam bidang seni sehingga mampu menghasilkan karya seni, ilmu kesenian, pemikiran metodologis seni, produk tekhnologi kesenian, dan SDM berwawasan kesenian. Begitu seterusnya. Ada dua poin penting dari narasi peradaban manusia dalam kajian ini. Yaitu, proses dan hasil. Proses tidak bisa diabaikan dari kehidupan manusia. Abai terhadap proses jelas tidak akan bisa menghasilkan produk sebuah peradaban.

Proses juga ada kaitannya dengan belajar. Alasannya sangat sederhana, belajar substansinya modifikasi tingkah laku². Tingkah laku sendiri dalam perspektif Sigmund Freud, memiliki kaitan erat dengan pengalaman: learning is defined as the modification or strengthening of behavior through expriencing ${ }^{3}$. Pengalaman hidup seseorang, dalam kesendirian dan interaksi sosial akan berimplikasi terhadap peradabannya. Semakin jelek pengalaman hidup seseorang, semakin kacau peradaban dirinya, generasi, dan masyarakatnya. Pengalaman dari sebuah proses itu menjadi teori metodis memunculkan hasil. Bagaimana tipologi metodis kalangan santri di lembaga pendidikan Islam salaf (tradisional) dan khalaf (modern) dalam mencapai hasil dari pengalaman belajarnya?

\footnotetext{
${ }^{1}$ Oemar Hamalik, Proses Belajar dan Mengajar, (Jakarta: Bumi Aksara, 2011), 5

${ }^{2}$ Wragg, C.E., Clasroom Teaching Skills, (News York: Nicholas Publishing Company, 1984), 45

${ }^{3}$ Oemar Hamalik, Proses Belajar dan Mengajar ... 10
} 


\section{Melacak Akar Historis Kegiatan Keislaman di Nusantara}

Pendidikan Islam mulai tumbuh di Indonesia pada sekitar abad ke-7, 10, dan ke 13 M. Yaitu, ketika sebagian penduduk mulai membuka diri berinteraksi dengan para pedagang dari luar nusantara. Baik pedagang dari Gujarat, Arab atau negara Eropa lainnya. Pada abad-abad tersebut, penduduk di Indonesia sebagian besar masih memeluk agama nenek moyang, yaitu hindu, budha, animisme, dan dinamisme. Bahkan, ada warga yang belum beragama sama sekali. Persentuhan warga pribumi dengan para pedagang ini membuka jalan panjang tergerusnya rasa dan kepercayaan masyarakat pribumi akan keyakinan yang sudah mendarah daging. Sebahagian warga mulai mengenal ajaran agama Islam yang dibawa oleh para pedagang dari luar Indonesia ini. Pada mulanya sebatas mengenal dan akhirnya meyakinya sebagai sumber ajaran kebenaran.

Dari data sejarah yang ada, para pedagang dari Arab, India dan Eropa bisa menginjakkan kaki ke Indonesia melalui jalur laut. Jalur laut menjadi rute termudah para pedagang untuk menjangkau sejumlah kawasan di Indonesia. Sehingga, sangat beruntung Indonesia memiliki sejumlah laut yang besar dan tersebar di sejumlah kawasan tanah air. Pelabuhan-pelabuhan yang ada di semenanjung tanah air, dalam sejarahnya adalah rute perlintasan para pedagang di sejumlah negara di dunia. Wabil khusus laut di Sumatera Utara dan Aceh Utara. Para saudagar banyak singgah di pelabuhan tersebut pada abad ke 7. Ada banyak perbedaan keterangan terkait maksud dari singgangahnya saudagar tersebut. Keterangan pertama, mereka singgah karena kepentingan mencari bahan makanan dan rempah-rempah. Ada keterangan lain, para Saudagar singgah karena kepentingan memasarkan barang dagangannya kepada masyarakat pribumi. Para saudagar dari tanah Makkah memasarkan barang dagangan berupa kain wori (wol) dan minyak wangi. Para saudagar yang singgah ke pelabuhan di Aceh dan Sumatera sangat beragam. Mulai dari Saudagar dari tanah haram, Persia, China dan India.

Interaksi antara mayarakat pribumi dengan para saudagar terus berlangsung. Pada babakan selanjutnya, interaksi berubah menjadi integrasi. Para saudagar tidak sekedar singgah di nusantara. Akan tetapi, mereka menetap dan berbaur dengan masyarakat. Sejumlah saudagar menikah dengan msayarakat pribumi, membuat 
komunitas muslim, dan masuk dalam sistem struktur sosial masyarakat pribumi saat itu. Dari tahap integrasi inilah, ajaran agama Islam terus menyusup dan mendarah daging ke berbagai pelosok nusantara. ${ }^{4}$ Masa integrasi mempermudah proses niaga para Saudagar dan memperlancar misi penyampaian ajaran Islam kepada masyarakat. Bahkan, sejumlah Pendakwah dari luar nusantara ini mendapat hati sejumlah raja di kawasan nusantara. ${ }^{5}$ Islamisasi terus berkembang. Para pedagang yang juga muballig ini lambat laun membuka ruang rasa simpati penduduk pribumi. Mereka secara pelahan-lahan membuka diri menerima ajaran yang mereka sampaikan secara total. Total yang dimaksud di sini, keyakinan yang mereka anut lambat laun tergantikan oleh ajaran agama Islam. Data empiris tentang islamisasi di Indonesia dibuktikan dengan ditemukannya sejumlah peninggalan yang mengarah kepada ajaran Islam. Seperti ditemukannya batu nisan Fatimah Binti Maimun di Leran Gresik (abad ke 11 M) bertuliskan kaligrafi (tulisan halus) berbahasa Arab dan perkampungan warga muslim di sejumlah pesisir nusantara sekitar abad ke $13 \mathrm{M}^{6}{ }^{6}$ Tahun demi tahun, dari awal kedatangan islam itu masyarakat di nusantara kemudian mengenal ajaran Islam lebih merata. Islam yang pada mulanya hanya diterima masyarakat di kawasan pesisir, akhirnya menyebar ke sejumlah kawasan di nusantara. Proses Islamisasi di Indonesia juga tak lepas dari peran serta para raja-raja yang memiliki pengaruh besar bagi warganya. Baik, di daerah Jawa, Sumatera, Aceh dan Kalimantan. ${ }^{7}$ Para Raja yang memeluk agama Islam akirnya diikuti oleh penduduk di daerah kekuasaannya. Asumsi yang terbangun, Raja sudah masuk Islam maka warga juga mengikuti jejak sang Raja.

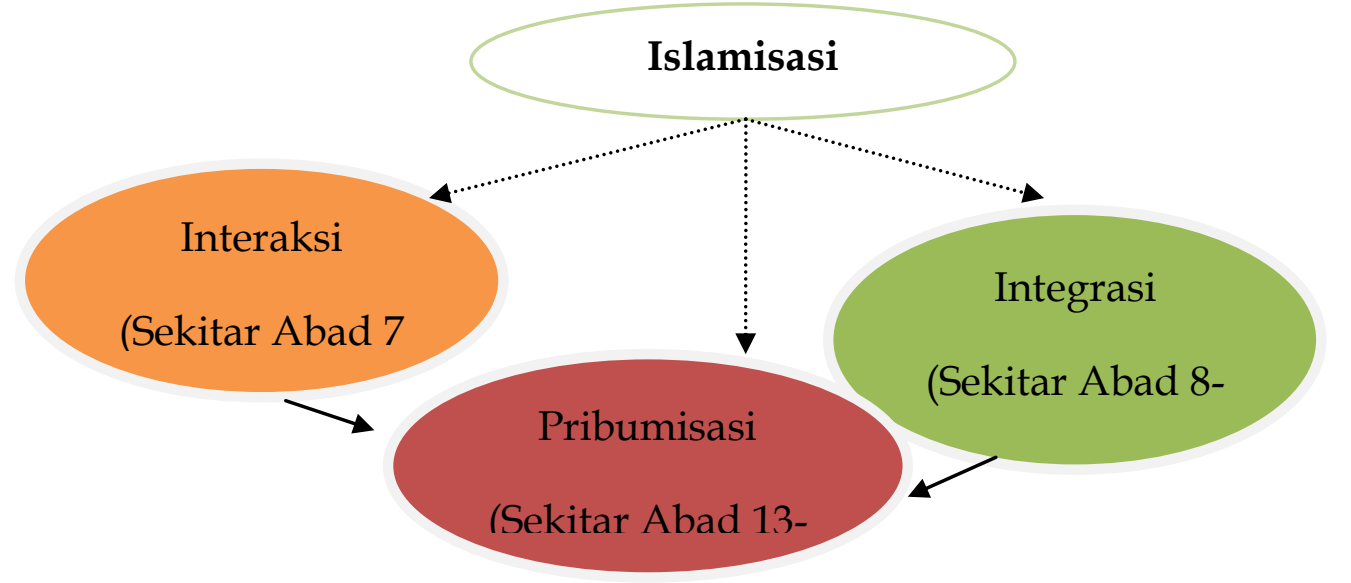

\footnotetext{
${ }^{4}$ Hanun Asrohah, Sejarah Pendidikan Islam, (Ciputat: PT. Logos Wacana Ilmu, 2011), 121.

${ }^{5}$ Badri Yatim, Sejarah Peradaban Islam, (jakarta: PT. Rajagrafindo Persada, 2011), 194

6 Ibid.., 198

7 Zuhairini, dkk., Sejarah Pendidikan Islam, (Jakarta: Bumi Aksara, 2001), 295
} 


\section{Tabel 7: Fase Islamisasi di Indonesia}

Pada masa awal pertumbuhan ini, hemat Penulis menjadi ruh bagi lahirnya sejumlah tempat (lembaga) pendidikan islam di Indonesia. Lembaga pendidikan Islam sendiri adalah sayap-sayap dari pendidikan Islam dalam batasan lebih global. Lembaga pendidikan Islam adalah tempat transformasi pendidikan Islam $^{8}$, di dalamnya terdapat kegiatan, metode dan materi yang disampaikan oleh Guru/Kiai/Ustadz. Di dalamnya, terdapat teori, metode dan sistem pendidikan Islam. Lembaga pendidikan Islam pertama di Indonesia dikelola dengan sangat sederhana. ${ }^{9}$ Para pengelola (tokoh agama Islam) memberikan pengetahuan agama Islam kepada warga/penduduk di sejumlah tempat. Mulai dari rumah penduduk, surau, langgar dan masjid-masjid. Tempat-tempat tersebut adalah lembaga pendididikan Islam pertama dan tertua di Indonesia.

Penyebutan terhadap lembaga pendidikan Islam di Indonesia sangat beragam. Tergantung konteks wilayah. Di belahan nusantara ada sekian istilah yang dipergunakan oleh sejumlah daerah. Maklum, fakta riil, Indonesia terkenal dengan kekayaan bahasa, dialek, dan budaya yang beragam. Di Aceh, lembaga pendidikan Islam pada masa awal pertumbuhan agama Islam adalah Meunasyah, Rangkang, Dayyah, dan Masjid. Sedangkan di Sumatera ada Surau dan Masjid. Di daerah Pulau Jawa, ada Langgar dan Pesantren. Di pulau Madura, lembaga pendidikan kegamaan tradisional adalah langgar (di eja dengan e), kobung, congkop, dan wekap.

\begin{tabular}{|c|c|c|c|}
\hline \multicolumn{4}{|c|}{ Lembaga Pendidikan Islam Tradisional } \\
\hline Aceh & Jawa & Sumatera & Madura \\
\hline $\begin{array}{l}\text { Meunasyah, } \\
\text { Rangkang, } \\
\text { Dayyah, dan } \\
\text { Masjid }\end{array}$ & $\begin{array}{l}\text { Langgar, Masjid, } \\
\text { Pesantren }\end{array}$ & Surau dan Masjid & $\begin{array}{lr}\text { Langgar/ Kobung/ } \\
\text { Congkop/ } \\
\text { Wekap }\end{array}$ \\
\hline
\end{tabular}

Tabel 8: Lembaga Pendidikan Tradisonal pada masa Awal

\section{Langgar: Lumbung Metode Pembelajaran Naturalis}

Di Madura, lembaga pendidikan Islam tradisional salah satunya berbentuk langgar (langgher; ejaan bahasa Madura). Langgar bagi masyarakat Madura dianggap

\footnotetext{
${ }^{8}$ H. Samsul Nizar, Sejarah Penddikan Islam, (Jakarta: Kencana Prenada Media Group, 2009), 173

${ }^{9}$ Ibid.., 123
} 
saksi bersejarah bagi peradaban Muslim pulau ini. Sebab, lewat lembaga pendidikan Islam tradsional ini, warga Madura mengenal tentang ajaran-ajaran agama Islam. Sebagaimana orang-orang Jawa dan warga Pribumi lainnya, orang-orang Madura pada masa awal memeluk agama Hindu, Budha dan bahkan tidak beragama sama sekali.

Langgar adalah lembaga pendidikan Islam pertama kali di Madura. Kondisi fisik langgar adalah bangunan segi empat dengan tiang-tiang penyanggah yang kesemuanya berbahan dasar kayu. Sebelum peradaban manusia madura berkembang, langgar dibuat dengan sederhana. Semua bahan bangunan diambil dari alam. Bahkan, atap bangunan langgar berbahan serai-serai daun kelapa yang biasa disebut dengan jhenur. Jhenur atau daun kelapa selain dibuat sebagai atap juga dimanfaatkan sebagai alas duduk. Sementara gedung sisi kanan dan kiri langgar dibuat dari bambu yang dianyam sangat rapi. Anyaman bambu ini dikenal dengan tabhing. Pada separuh abad ke 19, yaitu ketika masa penyebaran islam oleh para Wali songo, langgar terus bertahan dengan keterbatasannya. Para Kiai yang menjadi pengasuh langgar-langgar ini memolas langgar menjadi lebih berkembang. Langgar yang sebelumnya hanya dimanfaatkan sebagai lembaga pendidikan Islam dengan materi ajar membaca al-Quan mulai disempurnakan. Anak-anak penduduk bisa belajar sejumlah ilmu pengetahuan selain membaca al-Quran. Seperti ilmu fiqih, bahasa Arab dan lainnya. Sampai akhirnya, langgar menginspirasi para pengelola mendirikan lembaga pendidikan Islam yang lebih maju. Seperti madrasah dan pondok pesantren.

\section{Madura, dan Pergerakan Langgar ke Madrasah Formal}

Penyebaran pendidikan Islam di Madura sebenarnya bisa di lihat dari bukti fisik tempat atau lembaga yang dijadikan media penyampaian materi pendidikan Islam. Ada tiga tempat pendidikan Islam, yaitu langgar, Masjid dan Madrasah. Langgar adalah tempat paling awal sebelum adanya masjid dan madrasah. Sehingga, bisa diklasifikasikan bahwa pertumbuhan pendidikan Islam di Madura bisa di bagi menjadi tiga masa. Masa langgar, masa masjid dan masa madrasah. Kajian kali ini hanya fokus terhadap tempat pendidikan langgar ${ }^{10}$, sebagai sumbu dan sumber lahirnya inspirasi tanpa pendidikan Islam lainnya.

\footnotetext{
10 Pradjarto Dirdjosanjoto, Memelihara Umat (Kiai Pesantren-Kiai Langgar di Jawa, (Jogjakarta: LkiS,1999), 116-117
} 
Perjalanan lembaga pendidikan Islam (langgar) ini menjadi bukti pengaruh ajaran agama Islam bisa diterima dengan total oleh masyarakat lokal Madura. Mereka (penduduk) seperti memendam rasa simpati dan memiliki terhadap keberadaan lembaga pendidikan Islam tradisional ii. Isilah lembaga pendidikan islam tradisional di sini untuk mempermudah objek kajian tentang pertumbuhan pendidikan Islam dari rentang waktu yang terus mengalami perubahan. Orang-orang Madura menganggap langgar adalah lembaga pendidikan paling afdhal (terbaik) bagi anak-anaknya. Keberadaan langgar di Madura sudah ada pada masa kerajaan-kerajaan di tanah nusantara sekitar abad ke 9-11. Langgar saat itu sudah ada namun belum memiliki fungsi tempat pembalajaran ilmu agama Islam. Sebab, pada masa itu sebagian besar masyarakat Madura masih belum mengenal agama Islam. Seiring perkembangan waktu, pada abad kemudian, setelah masa dakwah para wali songo (abad ke 17) maka ajaran Islam mulai menyebar ke seantero tanah Jawa dan Madura.

Langgar, dalam praktiknya diasuh oleh seorang tokoh agama yang disebut Kiai. Ada juga yang menyebut $K e A j h i^{11}$. Kiai yang mengasuh langgar di mata masyarakat Madura memiliki citra dan kharima yang luar biasa. Dawuh atau kata-kata seorang Kiai (pada masa awal penyebaran Islam) adalah nasehat yang akan diterima dengan cepat oleh masyarakat. Seorang Kiai memiliki kemampuan dalam bidang agama dan ilmu kehidupan sosial lainnya. Sampai hari ini, citra dan kharisma Kiai masih terus kuat di tengah-tengah masyarakat Madura.

Terlepas dari kajian Kiai, langgar termasuk fasilitas pertama pendidikan Islam yang jauh melampaui masa kemajuannya. Maksudnya, meski bentuk fisik langgar sangat sederhana namun sudah mampu membentuk kepribadian lulusan yang luar biasa. Anak didik dari lembaga pendidikan Islam tradisional bernama langgar ini mampu menerapkan teori yang diajarkan guru/ustadz. Bahkan, jebolan langgar pada masa itu menjadi tokoh masyarakat. Seperti menjadi guru agama, dai dan tokoh-tokoh berpengaruh lainnya. Kesederhanaan bentuk fisik langgar pada masa itu tidak membuat sederhana pola pandang dalam menerima ilmu pengetahuan keagamaan. Terbukti, anakanak yang belajar di langgar memiliki ketelatenan, sikap disiplin (istiqamah) dan hormat (tazim) kepada gurunya. Mereka tanpa disuruh bisa mengerjakan aktifitas rutin yang dilaksanakan di langgar seperti membaca bait-bait kalimat toyyibah/kalimat pujian

${ }^{11}$ Istilah ini familiar di kawasan Guluk-guluk, kabupaten Sumenep, Madura. 
terbaik (seperti tahlil) sebelum dan sesudah melaksanakan kegiatan rutin belajar mengajar (membaca al-quran).

Selain sebagai tempat belajar ilmu al-Quran, langgar bagi masyarakat Madura memiliki manfaat serbaguna. Diantaranya, majlis talim dan acara kompolan. Majlis talim identik dengan kegiatan siraman ruhani. Sedangkan kompolan kegiatan yang sifatnya sosial, seperti arisan bulanan atau mingguan. Kompleksitas manfaat langgar ini kemudian menjadi rujukan sebagian masyarakat untuk mengembangkan keberadaan madrasah yang tradisional non formal menjadi lembaga pendidikan agama Islam yang formal. Madrasah membutuhkan satu bangunan sistem lebih rapi dan terkelola dengan profesional. Maka pada sekitar dekade tahun 70 an, sejumlah langgar mengembangkan dirinya membentuk bangunan sistem pendididkan islam lebih sistematis. Para kiai yang mengasuh langgar mendirikan bangunan untuk anak yang ingin melanjutkan pendidikannya ke jenjang lebih tinggi. Jadilah areal langgar tersebut sebagai komplek yang menjadi tempat mukim anak-anak belajar ilmu pendidikan Islam. Lambat laut langgar bermetamorfosa menjadi fasilitas belajar lebih formal. Anak-anak bisa belajar berbagai materi ilmu pengetahuan. Pada babakan selanjutnya, langgar menjadi salah satu dokumen sejarah yanga mendandai perkembangan pendidikan Islam di Madura. Seperti, madrasah dan pondok pesantren.

\section{Elastisitas Langgar sebagai Lembaga Pendidikan Islam Bergengsi}

Mengapa langgar menjadi lembaga pendidikan Islam pertama di Madura yang tidak pernah pudar hingga saat ini? Ada dua pendekatan yang bisa dipergunakan untuk mengamati pertumbuhan langgar sebagai lembaga pendidikan Islam. Yang pertama, pendekatan kebudayaan. Orang-orang madura terkenal dengan komunitas yang sangat menghargai serta menghormati kearifan budaya lokal. Meski sudah memiliki keyakinan ajaran agama Islam, namun masyarakat tidak pernah melupakan akar dasar terbentuknya masyarakat Madura. Sejumlah kebudayaan yang dilahirkan dari produk nenek moyang terus dipertahankan. Uniknya, langgar selama ini tidak pernah membentur rasa penghormatan orang-orang madura terhadap kebudayaan yang suda ada. Pengelola langgar dan pihak yang bersetuhan langgar justru menjadikan kebudayaan sebagai palang pintu untuk menarik masyarakat mencintai langgar yang di dalamnya terdapat misi menanamkan ajaran keagamaan (Islam). 
Salah satu bukti langgar tidak pernah membentur kebudayaan yang sudah terbangun sejak dulu yaitu terlaksananya sejumlah kegiatan yang sifatnya khas. Seperti pelaksanaan kompolan pembacaan macopat (tembang-tembang nasehat) yang sering digelar di langar-langgar. Sikap elastis pengela langgar dalam mengakomudir kepentingan warga ini menjadi umpan balik yang positif. Warga semakin merasa memiliki terhadap keberadaan langgar. Yang kedua, pendekatan akademik. Sejak awal warga menjadikan langgar sebagai tempat menempa diri sebagai pribadi yang shaleh (baik). Di langgar warga menemukan informasi tentang pengetahuan agama Islam. Mulai dari persoalan ibadah, amaliyah syariyah dan hakekat kehidupan (spritual quotion). Sebagian besar penduduk menyadari bahwa pengetahuan yang didapat langgar bisa menjadi bekal dalam menjalani kehidupan yang lebih luas. Anak-anak dan orang tua sama-sama menjadikan langgar sebagai tempat belajar ilmu agama Islam, sampai hari ini.

Pada era langgar, sistem yang dipergunakan berakar kepada keihlasan semata. Belum ada kurikulum dan menajemen pengelolaan seperti produk zaman mutaakhir ini. Namun, kegiatan pembelajaran bisa berlangsung dinamis dan harmonis. Seorang Kiai bisa molang (mengajar) dengan baik. Anak-anak yang menerima meteri ajar dari sang Kiai bisa dengan mudah menerima dan mempraktikkan. Intinya, mereka tidak pernah terkekang dengan manajemen formalitas dan lebih memilih sistem keakraban satu sama lain. Sisi dinamis dan harmonis semacam ini menjadi titik analisis untuk mengamati perkembangan pendidikan islam secara umum dan lembaga pendidikan islam secara khusus di nusantara ini. Mengapa lulusan sebuah lembaga pendidikan Islam di era modern tidak seoptimal pada masa era langgar? Pada sisi kognitif lulusan lembaga pendidikan islam era modern bisa berbangga, sebab anak didik sudah banyak mengetahui banyak hal hal tentang bidang agama dan umum. Akan tetapi, pada sisi keterampilan (psikomotor) terutama sikap (afektif) lulusan era modern masih belum seperti yang diharapkan. Ada sejumlah kasus yang bisa diamati di sejumlah kegiatan pembelajaran lembaga pendidikan Islam. Salah satu contoh, anak didik tidak kurang hormat terhadap guru. Saat mereka mengikuti kegiatan belajar mengajar kurang respon dan sering abai dengan keterangan dari guru/ustadz. Anak didik lebih mengedepankan nalar kognitif ketimbang afektif yang sejatinya adalah jantung dari perjalanan hidup mereka. Pengetahuan tanpa diimbangi sikap yang baik hanya akan sia-sia. 
Berbeda dengan era langgar. Anak didik sangat menghormati Kiai/Guru/Ustaz dalam setiap kesempatan serta situasi dan kondisi apapun. Mereka lebih mengedepankan nalar afektif dan menjadikan kognitif bagian penyeimbang dari sikap yang akan mengarahkan gerak langkah mereka. Sehingga, terbangun komitmen belajar untuk mengamalkan pengetahuan bukan belajar hanya sekedar mengetahui ilmu pengetahuan. Seperti pesan Nabi dalam sebuah hadis, al ilmu bilaa amalin ka al-sajarin bila tsamariin (ilmu tanpa diamalkan bagaikan pohon tak berbuah). Lembaga pendidikan Islam tradisional seperti langgar pada prinsipnya memiliki konsep pembelajaran yang inovatif. Dalam arti, langgar sudah berhasil mencipatakan situasi dan kondisi pembelajaran harmonis dan dinamis. Target pencapaian tiga variabel (kognitif, psikomotor dan afektif) mampu dicapai dalam batasan fasilitas yang (kebetulan) memang terbatas (pada masanya). Hebatnya, lembaga pendidikan Islam tradisional ini sejak awal berhasil menjadi media penyelamat generasi bangsa. Anakanak penduduk (khususnya di Madura) bisa mengenyam ilmu agama tanpa harus terpengaruh dan terkekang dengan ketentuan formalitas. Formulasi positif keberadaan lembaga pendidikan Islam tradisional seperti langgar dan lainnya mutlak menjadi rujukan mengembangkan lembaga pendidikan Islam yang sudah berkembang selama ini. Perkembangan lembaga pendidikan Islam di era modern ini pada prinsipnya selalu memegang ajaran langgar dalam hal semangat pengabdiannya. Sementara dalam hal pengembangannya tetap berakumulasi dengan kecanggihan ilmu pengetahuan dan tekhnologi. Setelah periode langgar, maka masyarakat muslim mulai mengembangkan prosedural pendidikan lebih sempurna. Langgar yang ada bermetamorfosis ke masjid.

Persamaan dan Perbedaaan Institusi pendidikan islam pada periode awal dan pertengahan dapat digambarkan sebagai berikut:

\begin{tabular}{|c|c|c|c|c|c|}
\hline \multirow[b]{2}{*}{ No } & \multicolumn{5}{|c|}{ Periode/Nama Institusi/Wilayah } \\
\hline & $\begin{array}{l}\text { Masa Nabi } \\
\text { Muhammad }\end{array}$ & $\begin{array}{l}\text { Khulafaur } \\
\text { Rasyidin }\end{array}$ & $\begin{array}{l}\text { Bani Abbasiyah } \\
\text { dan Bani } \\
\text { Umayah }\end{array}$ & Di Indones & \\
\hline 1 & $\begin{array}{l}\text { Rumah (Darul } \\
\text { al-Arqam) dan }\end{array}$ & $\begin{array}{l}\text { Kuttab, } \\
\text { Halaqah, } \\
\text { Badiah, }\end{array}$ & $\begin{array}{l}\text { Masjid, } \\
\text { Perpustakaan, } \\
\text { Rumah Sakit, }\end{array}$ & $\begin{array}{l}\text { Meunasah } \\
\text { Dayyah } \\
\text { Surau }\end{array}$ & $\begin{array}{r}\text { (aceh), } \\
\text { (Sumatera) } \\
\text { (Sumatera), }\end{array}$ \\
\hline
\end{tabular}




\begin{tabular}{|c|c|c|c|c|}
\hline & Kuttab & $\begin{array}{l}\text { Suffah dan } \\
\text { Masjid }\end{array}$ & $\begin{array}{l}\text { Madrasah, } \\
\text { Universitas }\end{array}$ & $\begin{array}{l}\text { Langgar (jawa), } \\
\text { Congkop/Langghar/kobu } \\
\text { ng (Madura), Masjid, } \\
\text { Madrasah, PTAI, UIN, } \\
\text { dan Pesantren }\end{array}$ \\
\hline & & & \multicolumn{2}{|l|}{ Materi } \\
\hline 2 & $\begin{array}{l}\text { Keagamaan } \\
\text { (Tauhid dan } \\
\text { Ahlak) }\end{array}$ & $\begin{array}{l}\text { Keagamaan } \\
\text { (Tauhid, } \\
\text { Ahlak, Ilmu } \\
\text { Al-Quran) }\end{array}$ & $\begin{array}{l}\text { Keagamaan } \\
\text { (Tauhid, Ahlak, } \\
\text { Ilmu Al-Quran, } \\
\text { Ilmu Bahasa } \\
\text { Arab, Ilmu Tata } \\
\text { Bahasa, Nahhu, } \\
\text { Sorrof, Tafsir } \\
\text { Al-Qur;an) } \\
\text { Umum: Ilmu } \\
\text { Filsafat, } \\
\text { Kedokteran, } \\
\text { Matematika, } \\
\text { Sejarah, } \\
\text { ilmu sosial }\end{array}$ & $\begin{array}{l}\text { Keagamaan (Tauhid, } \\
\text { Ahlak, Ilmu Al-Quran, } \\
\text { Ilmu Bahasa Arab, Ilmu } \\
\text { Tata Bahasa, Nahhu, } \\
\text { Sorrof, Tafsir Al-Qur;an) } \\
\text { Umum: Ilmu Filsafat, } \\
\text { Kedokteran, Matematika, } \\
\text { Sejarah, dan ilmu sosial, } \\
\text { Bahasa Asing, dan } \\
\text { disiplin ilmu yang } \\
\text { bersifat nasional. }\end{array}$ \\
\hline \multicolumn{5}{|c|}{ Metode Pengajaran } \\
\hline 3 & $\begin{array}{l}\text { Ceramah, } \\
\text { Diskusi dan } \\
\text { Tanaya Jawab }\end{array}$ & $\begin{array}{l}\text { Ceramah, } \\
\text { Diskusi, } \\
\text { Menghafal, } \\
\text { dan Tanaya } \\
\text { Jawab }\end{array}$ & $\begin{array}{l}\text { Ceramah, } \\
\text { Diskusi, } \\
\text { Menghafal, dan } \\
\text { Tanya Jawab, } \\
\text { Partisipatori, } \\
\text { Problem Solving }\end{array}$ & $\begin{array}{lr}\text { Ceramah, } & \text { Sorogan, } \\
\text { Bandungan, } & \text { Wetonan, } \\
\text { Diskusi, Menghafal, dan } \\
\text { Tanya } \\
\text { Partisipatori, } \\
\text { Solving }\end{array}$ \\
\hline
\end{tabular}




\begin{tabular}{|c|c|c|c|c|}
\hline \multicolumn{5}{|c|}{ Produk (Unsur Manusia) } \\
\hline 4 & Muslim & $\begin{array}{l}\text { Muslim, } \\
\text { Hafidz, } \\
\text { Muhaddis }\end{array}$ & $\begin{array}{l}\text { Ahli Taffaqquh } \\
\text { fiddin dan } \\
\text { Ilmuan Muslim }\end{array}$ & Santri, Kiai dan Sarjana \\
\hline
\end{tabular}

Tabel 8: Lembaga Pendidikan Islam dari Masa ke Masa

\section{Dari Langgar Beralih ke Pondok Pesantren: Meruwat Metode Belajar Santri}

Pondok pesantren dari segi operasional sistem formalnya bisa dikategorikan menjadi dua. Pondok pesantren yang menganut sistem salafiyah (tradisional murni) dan sistem khalafiyah (sistem salafiyah-modern). Perlu ditegaskan, pada prinsipnya pondok pesantren yang ada di sejumlah kawasan Indonesia mempergunakan mekanisme salafiyah (tradisional). Namun, seiring perubahan zaman dan perkembangan ilmu pengetahuan dan tekhnologi, konsep tradisional mengalami modifikasi lebih modern. Sehingga, pelabelan tradisonal substansinya adalah sebatas ikon khas bagi lembaga pendidikan Islam pondok pesantren. Istilah salafiyah dipergunakan untuk memfasilitasi satu komunitas yang konsisten mempertahankan budaya ulama-ulama masa lalu. Mulai dari sisi fasilitas, materi ajar, prosedural operasional, dan mekanisme kerja sebuah aktifitas. Atas dasar ini maka muncul istilah pondok pesantren salafiyah. Istilah salafiyah untuk memberikan ruang pembatas antara kemajuan masa lalu dengan kemajuan setelahnya. Konsep tradisonal bukan menjadi alat ukur kemajuan sistem permanen. Namun, hanya untuk menjembatani kemajuan dari masa ke masa. Pertumbuhan pondok pesantren masa awal tidak bisa dibandingkan dengan kemajuan pada masa setelahnya.

Khalafiyah sering diartikan dengan baru/mdern. Pondok pesantren khalafiyah substansinya adalah salafiyah. Pemaknaan khalafiyah karena sudut kajian terhadap pesantren ini adalah ruang terbuka terhadap perkembangan ilmu pengetahuan dan tekhnologi. Sehingga, pondok pesantren khalafiyah lebih dikenal dengan ciri khas materi, prosedural, sistem dan fasilitas yang dipergunakan memasukkan unsur-unsur baru. Seperti, diberlakukan kegiatan pendidikan formal sesuai ketentuan sistem pendidikan nasional, fasilitas mempergunakan produk modern, dan sistem yang dipergunakan mempergunakan mekanisme formal. 
Sangat sulit membedakan salafiyah dengan khalafiyah di abad 21 ini. Sebagian pondok pesantren di Indonesia melebarkan sayap dan mengembangkan sejumlah komponen di dalamnya. Sehingga, istilah salafiyah dan khalafiyah itu ada sebatas untuk mengklasifikasi dominasi materi dan prosedural masal lalu dan perubahan masa kini. Ciri verbal pondok pesantren Salafiyah bisa diperhatikan dari pengelolaan organisasi, kurikulum yang dipergunakan, dan fasilitas yang dimanfaatkan. Adapun ciri-ciri verbal diantara kedua jenis pondok pesantren ini sebagai berikut: 


\begin{tabular}{|c|c|c|c|c|c|c|}
\hline \multirow{4}{*}{ 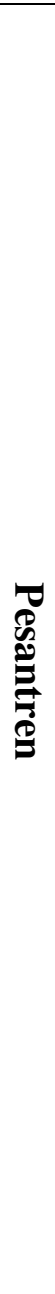 } & \multirow[b]{2}{*}{ Jenis } & \multirow[b]{2}{*}{$\begin{array}{l}\text { Managemen } \\
\text { Organisasi }\end{array}$} & \multicolumn{3}{|c|}{ Kurikulum } & Fasilitas dan Metode \\
\hline & & & $\begin{array}{l}\text { Payung } \\
\text { Hukum }\end{array}$ & $\begin{array}{l}\text { Sumber } \\
\text { Rujukan }\end{array}$ & $\begin{array}{l}\text { Jenjang } \\
\text { pendidika } \\
\text { n }\end{array}$ & Media dan Metede Pembelajaran \\
\hline & Salafiyah & $\begin{array}{l}\text { Sentralisasi } \\
\text { (Semua tugas, } \\
\text { urusan } \\
\text { menyangkut } \\
\text { kegiatan } \\
\text { pesantren } \\
\text { ditangani oleh } \\
\text { Kiai/ Pengasuh } \\
\text { Pondok } \\
\text { Pesantren) }\end{array}$ & $\begin{array}{l}\text { Kurikulum } \\
\text { Pesantren }\end{array}$ & $\begin{array}{l}\text { Literatur } \\
\text { Keislaman } \\
\text { Berbahasa Arab } \\
\text { (kitab turas) }\end{array}$ & $\begin{array}{c}\text { Non } \\
\text { Kelasikal }\end{array}$ & $\begin{array}{l}\text { Alamiyah (Memanfaatkan potensi alam dan tanpa } \\
\text { intervesi praduk tekhnologi modern. Contoh, } \\
\text { bangunan funduknya berbahan alam) }\end{array}$ \\
\hline & Khalafiyah & Koperasi & $\begin{array}{l}\text { Kurikulum } \\
\text { Nasional }\end{array}$ & $\begin{array}{lr}\text { Literatur } & \text { Ilmu } \\
\text { Agama } & \text { dan }\end{array}$ & Kelasikal & $\begin{array}{l}\text { Ilmiah (Bahan, fasilitas yang dipergunakan sudah ada } \\
\text { intervensi ilmu pengetahuan dan produk tekhnologi }\end{array}$ \\
\hline
\end{tabular}




\begin{tabular}{|l|l|l|l|l|l|l|}
\hline & & & Umum & & modern $)$ \\
\hline
\end{tabular}


Tabel 8: Perbedaan antara Pondok Pesantren Jenis Salafiyah dan Khalafiyah

Pondok pesantren juga merupakan lembaga pendidikan Islam bergengsi di bumi Indonesia. Pondok pesantren ditengarai sudah ada di Indonesia sejak masa awal penyebaran agama Islam. Akan tetapi, data lebih kongkrit pondok pesantren tumbuh dan berkembang sekitar abad ke 13 sampai ke 19 M. Yaitu, setelah islamisasi mencapai tahap pribumisasi. Berkembang yang penulis maksudkan, ruh pesantren sudah menyebar ke seluruh pelosok nusantara. Pergerakan Pondok pesantren tidak bisa lepas dari proses Islamisasi di Indonesia. Akan tetapi, sejumlah kajian ilmu keislaman Indonesia, mengidentikan pondok pesantren dengan islamiasi pada masa kerajaan. Islam tersebar di Indonesia bisa dikategorikan ke dalam tiga masa. Yaitu, masa kerajaan, masa muballigh, dan masa santri. Pada masa kerajaan, Islamisasi lebih banyak dilakukan untuk mengajak sejumlah raja-raja yang pada awalnya menganut agama Hindu dan Budha untuk memeluk agama Islam. Pada masa kerajaan ini, kiprah para Wali Songo di pulau Jawa banyak dibahas dalam kajian sejarah islamisasi di Indonesia. Bahkan, istilah pesantren menjadi istilah baku yang dipergunakan memfasilitasi lembaga pendidikan keislaman yang memliki varibael masjid, santri, kiai, dan proses pengajaran keislaman.

Sedangkan masa muballigh adalah masa para sunan dan ulama-ulama di nusantara. Setelah masa kerajaan hampir berakhir, para penyebar ajaran Tuhan ini terus melanglangbuana menyebarkan ajaran islam ke semua pelosok nusantara. Para muballigh ini akhirnya mendirikan sejumlah tempat permanen sebagai pusat penyebaran dakwahnya. Warga sekitar yang mendengar info para Wali dan Muballigh berdakwah akhirnya berbondong untuk mempa diri. Sejumlah warga yang datang dari berbagai penjuru belajar ilmu agama. Mereka menetap dalam masa tertentu untuk belajar ilmu agama. Mereka yang belajar dengan cara menetap dalam waktu yang sekian lama di tempat atau kediaman sang muballigh lazim disebut dengan santri. Sementara semua komponen yang ada pada proses kegiatan belajar mengajar di sebuat dengan pondok pesantren.

Dalam sejumlah kajian dijelaskan, istilah pesantren merupakan literatur khas Jawa. Hal itu bisa dilacak dari akar kata santri, kiai, tradisi khas yang dimiliki pesantren. Kata kiai, dalam pandangan masyarakat Jawa merupakan kata untuk memfasilitasi benda yang dikeramatkan, benda yang memiliki kekuatan alam, berbeda dengan benda lainnya. Seperti tombak atau keris yang dianggap memiliki kedahsyatan supranatural. Lambat laun, setelah para muballigh (wali songo) datang mengislamkan tanah Jawa, mereka dianggap memiliki kekaramatan ${ }^{12}$ yang berbeda dengan masyarakat lainnya. Selain itu literature khas Jawa juga terlihat pada kata santri. Menurut keterangan, santri berasal dari kata cantrik. Cantrik memiliki arti seorang murid yang selalu

\footnotetext{
12 Zaitur Rahem, Jejak Intelektual Pendidikan Islam, (Yogyakarta: CV. Pustaka Ilmu, 2016), 67
} 
mengikuti gurunya kemanapun pergi. Ada juga keterangan yang menjelaskan, santri berasal dari bahasa India Shastri yang berarti orang yang faham terhadap kitab-kitab agama hindu ${ }^{13}$.

\section{Tabel 9: Komponen Pondok Pesantren}

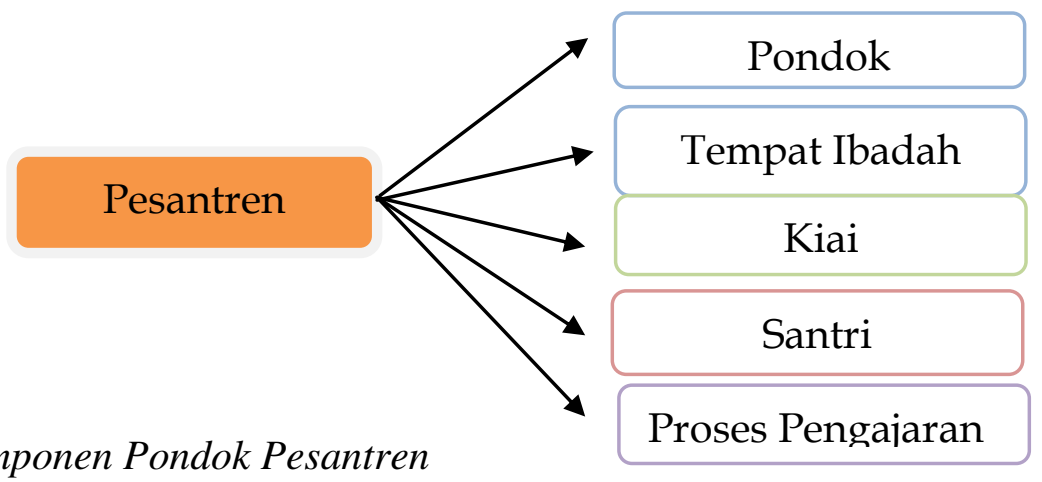

Pondok pesantren terkenal dengan tradisinya yang khas. Karena itulah, Nurcholish Madjid menyebut pesantren sebagai lembaga pendidikan indigenuous; produk budaya asli Indonesia. ${ }^{14}$ Pesantren sejak awal sampai hari ini dianggap sebagai lembaga pendidikan yang mampu konsiten mempertahankan tradisinya ${ }^{15}$. Sehingga, pesantren dianggap sebagai benteng kuat negara Indonesia dalam menjaga moral generasi bangsa ${ }^{16}$. Sejak masa awal pertumbuhannya, pesantren menerapkan metode pembelajaran yang khas juga. Adapun metode pengajaran yang diberlakukan adalah: Pertama, Wetonan/Bandungan. Yaitu cara pengajaran dengan ciri khas pendidik (Kiai) membacakan materi ajar (isi kitab) di depan para santri. Sedangkan para santri juga memegang teks dari kitab yang sama yang dibacakan oleh Kiai. Adapun kitab yang lazim dipelajari atau dikaji adalah kitab karangan ulama-ulama terdahulu. Seperti kitab tafsir al-Jalalain, Fathu al-Qarib, Jurmiyah, Ibnu Aqil, dan kitab sejenis lainnya. Kedua, Sorogan. Yaitu metode yang memiliki ciri khas santri secara perseorang membacakan kitab kepada Kiai. Seorang Kiai mengamati hasil bacaan dari santri yang membaca. Metode ini dalam teori modern disebut dengan metode belajar secara private. Metode sorogan dilaksanakan biasanya untuk mengasah ketangkasan santri dalam membaca dan memberikan arti secara benar kitab yang notabene tidak berharkat. Metode ini dianggap efektif untuk memepercepat pemahaman santri dalam membaca dan memberikan makna terhadap kitab gundul berdasar kaidah ilmu tata bahasa Arab (nahhu dan sharraf). Ketiga, Hafalan. Metode ini memiliki ciri khas seorang santri menghafal teks-teks liteatur bahasa Arab. Kebiasaan di sejumlah pondok pesantren, hafalan lebih ditekankan kepada literatur ilmu tata bahasa. Seperti baitbait ilmu nahhu dan sorrof. Menghafal dinilai efektif karena memiliki fungsi sebagai pisau analisa

\footnotetext{
${ }^{13}$ Haidar Putra Daulay, Sejarah Pertumbuhan dan Pembaharuan Pendidikan Islam di Indonesia, (Jakarta: Teras, 2007), 61

14 Nurcholish Madjid, Bilik-Bilik Pesantren: Sebuah Potret Perjalanan, (Jakarta: Paramadina, 1997), 3

${ }^{15}$ KH. Abdurrahman Wahid, Menggerakkan Tradisi (Yogyakarta: PT. LkiS, 2010) 5-6

16 Samsul Nizar, Sejarah Pendidikan Islam: Menelusuri Jejak Sejarah Pendidikan Era Rasulullah Sampai Indonesia, (Jakarta: Kencana Prenada Media Group, 2011), 289
} 
ketika seorang santri hendak membaca secara tepat dan benar teks yang tidak berharkat. ${ }^{17}$ Keempat, Bahtsul Masail (problem solving). Metode ini dipergunakan untuk menganalisa satu persoalan dengan mengupulkan sejumlah referensi sebagai alternatif jawaban dari persoalan yang dikaji. Di sejumlah pondok pesantren pada mulanya kegiatan ini dimotori oleh para Kiai. Akan tetapi, seiring perubahan dan perkembangan zaman, metode ini menjadi kegiatan rutinitas pondok pesantren yang ditangani langsung pengurus pondok pesatren atau santri senior.

\section{Penutup}

Kebiasaan belajar elemen pesantren pada masa awal — bahkan hingga sekarang- menjadi cermin peradaban belajar bergengsi. Terbukti, sejumlah lulusan dari lembaga pendidikan pesantren dmampu berdiealektika dengan masyarakat. Mereka bisa bergabung dan berbaur bersama warga sekitar, dengan pengalaman yang sudah didapat selama belajar di pondok pesantren. Metode hafalan, sorogan, wetonan, dan bahtsul masail pada prinsip merupakan bangunan belajar paling prinsipil dan lembaga pendidikan khas nusantara. Meskipu, dalam praktik-legalis, perlu ada renovasi kontektualis. Sebab, perubahan dan perkembangan zaman menuntut adanya peran semua komponen untuk mendukungnya. Mengabiakan kemajuan tidak baik. Namun, melepas kebiasaan baik yang sudah ada secara turun temurun juga tidak baik. Realitas cara belajar komponen santri sejak masa awal substansinya masih up date untuk diterapkan pada masa ini. Tinggal bagaimana teori yang sudah ada bisa disinergikan dengan konteks yang berkembang. Peradaban maju ditandai oleh terbukanya komunitas terhadap setiap kemajuan. Jauh sebelum masyarakat mengenal produk tekhnlogi, nenek moyang di negeri ini sudah melakukan penjelajahan maritim ke semua pelosok dunia. Saat ini, tibalah bagi kita semua untuk melanjutkan tradisi pencaharian jati diri menuju kearah peradaban lebih maju.

17 Abudin Nata, Sejarah Pendidikan Islam,(Jakarta: PT Raja Grafindo, 2004), 287 


\section{Daftar Pustaka}

Abdullah (Ed.), Taufik, 1991, Sejarah Umat Islam Indonesi , Jakarta: Majelis Ulama Indonesia.

Asrohah, Hanun, 2000, Sejarah Pendidikan Islam, Ciputat: PT. Logos Wacana Ilmu.

Ami, Ahmad, 1987, Islam dari Masa ke Masa, Bandung: CV. Rusyda,

Al- Atta, Syed Muhammad Naquib, 1990, Islam dalam Sejarah dan Kebudayaan Melayu, Bandung: Mizan.

Brockelmann, Carl, 1982, History of the Islamic Peoples, London: Roudledge \& Kegan Paul.

Muhaimin, 2010, Pengembangan Kurikulum Pendidikan Agama Islam, Jakarta: PT. Raja Grafindo.

Nizar, Samsul, Sejarah Pendidikan Islam: 2011, Menelusuri Jejak Sejarah Pendidikan Era Rasulullah Sampai Indonesia, Jakarta: Kencana Prenada Media Group.

Rahem, Zaitur, 2016, Jejak Intelektual Pendidikan Islam (Yogyakarta: CV. Pustaka Ilmu.

Pustaka, 2015, Risalah Pendek Menulis Resensi Buku ,Yogyakarta: Ganding

Sanjaya, Wina. 2009, Kurikulum dan Pembelajaran: Teori dan Praktik Pengembangan KTSP. Jakarta: Kencana.

Yatim, Badri, 2008, Sejarah Peradaban Islam, Jakarta: PT. Raja Grafindo. 